\title{
EXERCISING SOUTHERN AND DECOLONIAL (SELF)CRITIQUE IN TRANSLANGUAGING: FOR A JUNTOS STANCE
}

\author{
Exercitando (auto)crítica sulista e decolonial em translinguagem: \\ por uma orientação juntos
}

\author{
Nara Hiroko Takaki \\ Universidade Federal do Mato Grosso do Sul \\ narahi08@gmail.com \\ http://orcid.org/0000-0001-8574-5842
}

\begin{abstract}
One of the issues in language studies revolves around dialogues. To dialogue with differences in productive ways presupposes respect and transgressive points of contact which envisage possibilities. Translanguaging/translingual practices, whose nature is southern and decolonial, struggle(s) for social justice recognizing all the resources and repertoires students and teachers use in the processes of knowledge construction. This created space cannot be domesticated and, therefore, it invites other ontologies-epistemologies-methodologies (TAKAKI, 2016, 2019a, 2020) ${ }^{1}$ in transit. This is the aim of this paper, that is, to try to expand the southern and decolonial perspectives (self)critically juntos based on a specific part of a lesson. The theoretical framework counts on notions of (self)critique, southern and decolonial features. A key point is the co-construction of questionings, with philosophical theory-practice bringing co-authorship in the interpretive market of meanings and more transcultural agency juntos. The final analysis highlights that although translanguaging/translingual practices is/are southern and decolonial, it/they can be amplified with (self)critical exercises juntos in the encounter with pluriversal texts and contexts in incessant and rhizomatic movements in which students, educators and authorities live.
\end{abstract}

KEYWORDS: Juntos (self)critique; Southern and decolonial perspectives; Translanguaging/Translingual practices; Teacher education and language teaching.

RESUMO: Uma das questões de estudos de línguas/linguagens gira em torno dos diálogos. Dialogar com as diferenças de modo produtivo pressupõe respeito e pontos transgressores de contato que vislumbrem possibilidades. A translinguagem/práticas translíngues, de caráter sulista e decolonial, luta(m) por justiça social reconhecendo todos os recursos e repertórios que os estudantes e professores usam no processo de

\footnotetext{
${ }^{1}$ In previous publications, I conceived ontology-epistemology-methodology as always already intertwined with each other $(2016,2019 a, 2020)$ as explained in this text.
} 
construção de conhecimento. Esse espaço criado não pode ser domesticado e por isso mesmo convida outras ontologiasepistemologias-metodologias (TAKAKI, 2016, 2019a, 2020) em trânsito. É esse o objetivo deste artigo, qual seja, tentar amplificar as perspectivas sulistas e decoloniais (auto)criticamente juntos tomando por base parte de uma aula. A base teórica conta com noções de (auto)crítica, letramento crítico, aspectos sulistas e decoloniais. Um ponto importante é a coconstrução de questionamentos, com teoriaprática filosófica trazendo coautorias no mercado interpretativo de sentidos e agência transcultural juntos. A ponderação final salienta que, embora a translinguagem/práticas translíngues seja $(\mathrm{m})$ sulista(s) e decolonial/decoloniais, ela(s) pode(m) ser ampliadas com exercícios (auto)críticos juntos no encontro com textos e contextos pluriversos em movimentos incessantes e rizomáticos em que estudantes, educadores e autoridades vivem.

PALAVRAS-CHAVE: (Auto)crítica juntos; Perspectivas sulistas e decoloniais; Translinguagem/Práticas translíngues; Formação de professor e ensino de línguas.

\section{INTRODUCTION}

People have used language in diverse and unimaginable forms much before the invention of cars, the discovery of DNA and the advent of the Internet. The impact of globalization, in fluxes, and the fast technological advances favor people to recreate the linguistic, social, cultural, political and economic landscapes. This scenario has been inviting scholars to reinterpret the world socially, culturally and historically to try to respond to old and emerging challenges in hybrid and sustainable ways. Inspired by the principles of critical education citizenship, that is, the promotion of education toward social justice (FREIRE, 2005; ZEICHNER, 2011), a form of pedagogical intervention has emerged. This pedagogical instruction, translanguaging ${ }^{2}$ (GARCÍA; WEI, 2014, GARCÍA; KLYEN, 2016; CREESE; BLACKLEDGE, 2010; LU; HORNER, 2013; OTHEGUY; GARCÍA; REID, 2015) /translingual practices (CANAGARAJAH, 2013a, 2013b, 2011) has/have the potential to develop bilingual/multilingual ${ }^{3}$ students' sense of critical consciousness (GARCÍA; JOHNSON; SLETZER, 2017, p. 167), "without clear boundaries of nations, territory and social groups" (GARCÍA; LIN, 2016, p. 5) and of the teachers with

\footnotetext{
${ }^{2}$ I prefer not distinguishing translanguaging from translingual practices. So, from now onwards, translanguaging/translingual practices will be used interchangeably.

${ }^{3}$ Given the complexity and embeddedness of language practices, the use of bilingual/multilingual is chosen here.
} 
a view to collaborate on identifying and transforming the social inequities surrounding them.

In various contexts, thinking, doing and living otherwise (WALSH, 2007) in contact zones (PRATT, 1991, SOUSA SANTOS, 2009) are called for. This demand entails a revision of educational paradigms starting from the schools as a site of permanent struggles. Teaching and learning in critical ways that coexist in complex and productive differences seem to be the norm from southern perspectives in language studies, at least in Applied Linguistics (PENNYCOOK; MAKONI, 2020).

Furthermore, it has been observed that digital communication, social networking with sophisticated smart phones have promoted space for authorial meaning making and collective agency (THE NEW LONDON GROUP, 1996) in the global scenario. It has been observed that more than 5120 million people use WhatsApp in Brazil, which means debates around (self)critique in life are desirable if the linguistic, social, cultural reconstructions in the Global South with the Global North represent one possible path. This path reconnects contestations of Western hegemonies and agency and counts on a decolonial option (MIGNOLO, 2018, 2007) and on southern perspectives (SOUSA SANTOS; MENDES, 2018, SOUSA SANTOS, 2009, MENESES DE SOUZA, 2019).

Aligning with this perception related to the changes in the local-global scenario, translanguaging/translingual practices advocate(s) in favor of more participative educators and institutions coexisting among bilingual/multilingual students coming from vulnerable contexts (or not so much) in the encounter with a powerful language such as English, or Portuguese in the case of Brazil. The English language (and the culture it is imbued with), as any other language has always been pluralized (CANAGARAJAH, 2013a, 2013b, 2011, PENNYCOOK, 1999, 2006). Such theorists departure from the Bakhtinian conception of language, which sees it as heterogeneous engendering and designing realities and realities modifying it.

While using language, speakers recreate textual/multimodal/discursive meanings together with the world around them. In this way translanguaging/translingual practices is/are not new. It/they also purport(s) to contest inflexible ways of teaching, learning, and being with the world (FREIRE, 2005). It is important to remember, however, that the implementation of translingual pedagogies might face resistance, at least in certain Brazilian contexts, on the part of the current authorities, who have influenced policy 
makers. For the purpose of illustration, the current federal government from the radical right wing, whose set of beliefs and interests lie in 'non-ideological' practices, has recently prohibited the use of controversial themes in the last high school national Brazilian examination for university entrance $\left(\mathrm{ENEM}^{4}\right)$. Under the current presidency, a commission of analysts was created on March, 2019, to forbid controversial themes. Thus, students sitting for the latest edition of such exam had to write an argumentative essay based on "Democratization of access to the cinema in Brazil".

Recognizing that we, educators, are also products of Cartesian epistemologies, in which rationality and objectivity contribute to the perpetuation of monolingual, graphocentric and routinized classes is a useful sign of (self)critique. As already reported, gatekeeping texts and exams, under the apparent banner of neutrality, are very much rooted in the dominant paradigms defended by specific groups in power. One of the consequences of such paradigms is that, apart from being insular from broader transcultural contexts (PENNYCOOK, 2006), linear models see teaching and learning from simple to more complex structures and subjects. Thus, one possible path to broaden the southern and decolonial translingual horizons might be (self)critique juntos 5 (GARCÍA; JOHNSON; SELTZER, 2017, p. 50) to empower the student's and teacher's selves backed up by the institutions in which they operate.

Seeing in this way, the aim of this paper is multifolded: first, I briefly characterize translanguaging/translingual practices. Then, I tackle on the notion of (self)critique juntos and I briefly focus on assessment while emphasizing southern and decolonial but in a creative, (self)critique juntos reflection. After that, in order to exemplify a lesson in which (self)critique seems to be missing, I present one of the lessons taught by a teacher, Stephanie $^{6}$, in a North-American context. In the last part, I seek to establish a conversation with this teacher to, juntos, rethink possible ways to expand reading in this very translingual lesson from creative, (self)critical southern, decolonial perspectives, which, perhaps, fit a world that is evolving rapidly.

\footnotetext{
${ }^{4}$ As a non-compulsory and standardized exam, National Examination for High School (ENEM) is managed by the Ministry of Education's National Institute for Educational Studies and Research (INEP) and it aims at testing the level of knowledge of the high school students in Brazil. It is used for students' enrollment in many Brazilian universities, according to information available at: <https://www.brazileducation.info/tests/ higher-education-tests/enem-in-brazil.html>.

${ }_{5}^{5}$ Such authors use the term juntos meaning together. From now onwards, juntos.

${ }^{6} \mathrm{I}$ opt for preserving her name, Stephanie, as in the cited publication.
} 


\section{GENERAL OVERVIEW OF TRANSLANGUAGING/TRANSLINGUAL PRACTICES}

Moving away from the hardships brought about by Westernized, modernist systems, the dense literature revolving around translanguaging/translingual practices (GARCÍA; WEI, 2014, GARCÍA; KLYEN, 2016, CREESE; BLACKLEDGE, 2010, LU; HORNER, 2013, OTHEGUY; GARCÍA; REID, 2015, CANAGARAJAH, 2013a, 2013b, 2011, among others) assumes a specific stance. It is geared to more fluid, dynamic, creative, critical and ethical epistemologies for productive conviviality among differences while working on planned and unprepared performativities on a daily basis.

Translanguaging/translingual practices invite(s) teachers and society to recognize people's 'total' resources. It/They favor(s) the legitimation of minoritized students' knowledge, intersubjectivity within others, domestic languages, and diverse forms of renegotiations of meanings (GARCÍA; WEI, 2014). Such richness also includes experiences, strategies for emergent negotiation of meanings and abilities for actions, which are broader than the language per se. They can and should have a place in contemporary lessons for citizenship literacies taking into consideration the landscape outlined in the introduction of this article.

As a pedagogical instruction (GARCÍA; WEI, 2014), the translingual paradigm draws on multiliteracies (THE NEW LONDON GROUP, 1996) coupled with multimodality (KRESS, 2010), whose rationale focuses on languages in action. Languages in action refer to the encounter of multiple meaning-carrying modes, such as: images, drawings, gestures, songs, performances and contingent agency from students' selflearning and collaborative learning, which merge into existing and emerging knowledge, linguistic and cultural identity.

Moreover, the translingual perspective increases students' self-confidence and well-being, an essential characteristic for present and future education with observable practices "centered in translanguaging corriente, dynamic translanguaging progression and translanguaging pedagogy" (GARCÍA; JOHNSON; SLETZER, 2017, p. xi). "To feel translanguaging corriente all you have to do is take a step back from your daily routine and listen and look [...] to listen sensitively to what students, colleagues, parents say and hear how it is being said" (GARCÍA; JOHNSON; SELTZER, 2017, p. xii). Through 
different tasks from different perspectives, general and specific linguistic performance, translanguaging pedagogy encompasses instruction and assessment intertwined with stance, design and shifts, in accordance with the cited authors. For that, two important components are fundamental: creativity and criticality (GARCÍA; WEI, 2014, p. 24) as tackled in the next part.

\section{ON CREATIVITY AND (SELF)CRITIQUE JUNTOS FOR ASSESSMENT FROM AND SOUTHERN DECOLONIAL PERSPECTIVE}

In this part, I channel the focus into two components: creativity and criticality (GARCÍA; WEI, 2014, p. 24) that go hand in hand, and which are important characteristics of translanguaging. They are defined respectively by García and Wei (2014, p. 67):

Creativity is the ability to choose between following and flouting the rules and norms of behavior, including the use of language. It is about pushing and breaking the boundaries between the old and the new, the conventional and the original and the acceptable and the challenging (emphasis added).

Criticality refers to the ability to use available evidence appropriately, systematically and insightfully to inform considered views of cultural, social, political and linguistic phenomena, to question and problematize received wisdom, and to express views adequately through reasoned responses to situations (emphasis added).

I draw on such notions to conceptualize (self)critique (otherwise) placing emphasis on the political aspect of the last citation. (Self)critique (otherwise) is not as a mere transformation but rather energy for waves of coliving outside the comfort zone not necessarily eliminating it. By coliving, I mean complex processes of meaning making that bring problematizations of a particular theme taking into account their implications in diverse linguistic and socio-cultural contexts. Such problematizations include interrogating what interests are met (or not, or not so much), under whose name, what form of knowledge construction is counted, and how they might reproduce social inequities (LUKE, 2012).

Coliving entails blending fluctuations of power relations, depending on the context of meaning making and that is why established truths and notions are never stable giving 
rise to undecidability (DERRIDA, 1997), ambiguity (RICOEUR, 1978) and hybrid, rhizomatic (DELEUZE; GUATTARI, 2005) and unknown/unrecognizable meanings. This might raise one's interest to choose to question his/her own and of the others' translanguaging/translingual practices. The aim is, therefore, to problematize it/them and to seek for other possibilities while reflecting on one's own intersubjectivity, creativity, (self)critique, ethics, authorship, agency and its implications in collective lives.

Students are likely to understand why social inequities exist and put forward projects for better conviviality, which I call coliving in less sedimented ways under certain conditions. Such conditions entail opportunity for the expansion of creativity and (self)critique while making meaning in classes, recognition of their coauthorship in the (re)design of activities and work on uneven relations of power in society to enhance their sense of citizens within differences and creativity,

If "Speaking a named language is a relation of partial overlap between a person's idiolect and the idiolects of others" as argued by Otheguy, García, Reid (2015, p. 297), then, it is possible to say that translanguaging opens space for coauthoring knowledge in the encounter of idiolects. This can be enhanced through creative strategies blending unknown knowledge, what they know and how they know it with knowledge coconstructed in other spaces.

(Self)critique is an ongoing work. It means looking at multidimensional mirrors in movement and allow myself to interrogate the historical origins of my prejudice against a person or something. To put it differently, my assumptions, social position, values, attitude, paradoxes should be revised each time I do produce discourses while interacting in a particular community, region, nation connected with the broader world. Also, how all these elements contribute to the promotion of certain identities, actions and ways of coliving to the detriment of others is to be monitored.

This educational practice helps me challenge my own notion of social justice, truths and realities in an unresolved task in transit with more collective interests in flux. I say unresolved task and in flux due to the internal collective heterogeneity revolving around local-global scales with different dislodging relations of power and paradoxes. It has the potential for renegotiations of meanings with authorities, colleagues and students aiming at more equal opportunities for people in highly vulnerable social conditions.

Going beyond mere reflexivity, (self)critique relies on philosophical processes 
"consisting always in inventing conceptions [...], but every conception is forcibly a paradox" (DELEUZE, 2003, p. 174). Corroborating this author, Rancière (2010) claims for dissensus rather than unproductive consensus (such as consensuses that assume takenfor-granted knowledge) as regards dialogues, which, means that self(critique) allows for our constant questioning of our own interpretive market in conflictual ways. In this way, (self)critique seeks to promote novelty in the resignification of self-dislocations juntos (GARCÍA; JOHNSON; SELTZER, 2017, p. 50), if this is what people wish to pursue. How it impacts (or not so much) research, teacher education, pedagogical practices in foreign language classroom and in society is a challenge at least in Brazil.

(Self)critique as a process of becoming emerges "under erasure" as a game, following Derrida (1997). As a way of coliving, it also recognizes that we constructed a past imbued with rationality that made us search for standardization in a powerful language, desiring equality among students and teachers as passive recipients (FREIRE, 2005) regulated by fixed ways of constructing the social arena of nations, race, class, ethnics, politics, religion and gender to mention a few. The task now seems to be moving beyond juntos, including the Global North and Global South for we-they share the same universe.

Concerning assessment in translanguaging, Otheguy, García and Reid (2016, p. 21) stress that:

To make sure that we are not misunderstood, we stress that we regard the ability for the bilingual to perform as a fluent user of a named language as a valuable skill, a worthwhile educational goal, and a legitimate thing to test for. Our point is that this is a specialized ability that is independent of general linguistic proficiency. Bilingual students who, irrespective of the labels that society puts on the lexical and structural features of their idiolect, can express themselves accurately, pleasantly, and successfully in the variety of communicative tasks we mentioned above, should be evaluated as possessing excellent linguistic proficiency. This positive assessment would be separate and independent of whether or how much these students translanguage.

Given that a positive assessment is important, as argued by the aforementioned authors, and to legitimize evaluations in this direction, it would be pertinent to reflect (self)critically upon questions, such as: To what extent devising a translingual ENEM for the migrants to compete with the Brazilian native speakers without changing the 
epistemology in which such an exam is founded would represent a decolonial change? How can we make the radical northern ontologies-epistemologies-methodologies ${ }^{7}$ (TAKAKI, 2016, 2019a, 2020), in which we are also reconstituted, more Derridian (and productive in terms of enactment ${ }^{8}$ ), southern (SOUSA SANTOS, 2018) and decolonial (QUIJANO, 2013, MIGNOLO, 2007, WALSH, 2007, among others) without totally rejecting the European concepts of subject, knowledge? And, instead of that, learning from rich diversity of democratic experiences in different parts of the world, “demodiversity”, as Sousa Santos (2018, p. 68) claims for.

(Self)critical inquiries presuppose complex interrogations such as the ones cited, which recognize that we are all complicit with the Eurocentric system and because of that, caution is on the horizon. It is possible to say translanguaging/translingual practices is/are decolonial educational instruction(s) in the sense that its/their rationale recognize(s) and values students' domestic languages/cultures, authorship, repertoires. A complementary decolonial aspect in translanguaging/translingual practices refers to the fact that it/they encourage(s) teachers and authorities to learn with other languages/cultures for 'better' conviviality.

At the same time, risks are par for the course in the southern and decolonial (self)critique juntos dialogue. Being conscious of such risks for societal coliving helps prevent teachers from accepting conformity and/or embarking on essentialist activism, that is, applying the same theory-practice to any context.

I go along with Kumaravadivelu's (2016) emphasis on a proactive, rather than reactive attitude, as indicated here:

with the view to reducing exhaustive and exclusive dependency on center-based knowledge system [...] paying attention to local exigencies of learning and teaching, identifying researchable questions, producing original knowledge, and subjecting it to further verification (KUMARAVADIVELU, 2016, p. 82).

\footnotetext{
${ }^{7}$ By ontology I mean my dynamic coliving within diversity/differences in ways that I can reposition my becoming leaving open space for expanded knowledge and relationship. I understand epistemology as a set of values and principles that inform knowledge in the plural and performed sense, that is knowledge constructed in diverse social situations not only in the academia. Methodology is a means to constantly reconstruct given ontology and knowledge. Social participation from the perspective of vulnerable people entails an interrelated view of these three components. If I support such people maintaining the elite's epistemology, I might become the same person with the same ontology without questioning my own assumptions and limit coliving.

${ }^{8}$ I see agency as initiation of an action and the effort/investment of energy to achieve the desired effect and enactment as the elaboration of interpretive procedures and strategies to deal with predictable and contingent aspects to think, act and colive otherwise.
} 
I understand southern and decolonial perspectives should be subject to permanent revisions including dialogues towards (self)critique juntos to avoid the construction of a translingual model-for-export. Recognizing the internal heterogeneity within similar groups and institutions is crucial as in the case of disenfranchised loci of knowledge construction and world understanding.

Kumaravadivelu's claims for "merely tinkering with the existing hegemonic system will not work; only a fundamental epistemological rupture will" (KUMARAVADIVELU, 2016, p. 80) might be, inadvertently, understood as a totalitarian notion of decoloniality and delinking (MIGNOLO, 2007). The risk of a radical rupture is that it might make room for another colonial matrix of power (QUIJANO, 2013). (Self)critique admits that many local agents may not be willing to accept the notion that the Global North paradigms (are heterogeneous) will not be erased/interrupted taking into account that we (from the South) have our own internal paradoxes, which invite us-them to reinvent forms of contamination $(\mathrm{XXX})$ that can be beneficial for rhizomatic (DELEUZE; GUATTARI, 2005) and imbricated sides.

Emerging critical educational policies within a neoliberal agenda, present in both the North and South paradigms, invite professionals and citizens to question our-their comfort zones. The generations of teachers, researches, parents and authorities can understand the politics of (self)critique in schooling and society as always at risk. In Brazil, for instance, resistance coupled with agency to subvert top-down colonized linguistic education implies attracting coordinators, principals, police makers and other stakeholders to start practicing life in self(critical)translingual mode in order to redesign classes, teacher education, language policy, curriculum design, ENEM and other official exams otherwise. As established in the introduction of this paper, my aim, now, is to present a lesson and, then, to try to expand on it juntos.

\section{OVERVIEW OF STEPHANIE'S LESSON}

In this part of the paper, I contextualize a lesson devised and implemented by Stephanie ${ }^{9}$ in an "English-medium $11^{\text {th }}$ grade social studies classroom in New York City"

\footnotetext{
9 "Stephanie is a teacher in New York [....]. She is of Polish descent and speaks a few words in Spanish and was trained as a History teacher. Her students have a wide range of experiences with oral and written Spanish and English. Some of them were born in the United States, one comes from the Republican
} 
(GARCÍA; JOHNSON; SELTZER, 2017, p. 129). I briefly reproduce what these authors report about her lesson aiming at illustrating translinguaging through this lesson in a bilingual context.

García, Johnson, Seltzer (2017, p. 134-135) account for a reading activity carried out by Stephanie, who is a native speaker of English but not a speaker of Spanish. On attempting to bring content-area and literacy together in her curriculum, she has her students ${ }^{10}$, with different experiences using English for academic purposes, engage with a trailer for a new movie about César Chávez ${ }^{11}$, which is followed by a discussion on what students knew about him. Perceiving the textbook brought a brief autobiography of the activist, Stephanie decides to resort to supplementary materials to create a space for debates on the target historical figure, "whose role in the movement was both important and controversial [...] in contributions to both the environmental movement and the struggle for human rights" (GARCÍA; JOHNSON; SELTZER, 2017, p. 130-131).

The aforementioned authors do not show the readers the supplementary texts Stephanie took from the Internet with the instructions and questions she uses to activate her students' knowledge of the world, cultural strengths to develop a sense of empowerment. Bringing in the story of a Mexican-American activist constitutes an ethical gesture, as evidenced in the analysis made by the researchers and displayed below:

Her stance reflects a social justice approach to teaching content. Stephanie supplemented the traditional curriculum with voices and stories that are often underrepresented, and pushed her students to see themselves and people like them as powerful agents of change in society (GARCÍA; JOHNSON; SELTZER, 2017, p. 131).

Next, Stephanie's students are given a handout with the picture of Chavéz and his biography in both English and Spanish versions to promote students' metalinguistic

Dominican, other from El Salvador, other from Ecuador, other from Guatemala. By organizing groups and giving credits to students' diverse resources, she widens students' authorship and responsibility to engage in complex content, in the use of diverse dictionaries bilingual texts, online translation, peer's translation and explanations, embracing emergent bilingual students feeling comfortable with them. This is the way she enacts her translanguaging stance" (GARCÍA; JOHNSON; SELTZER, 2017, p. 4).

${ }^{10}$ Eddy is Dominican and has excellent English oracy and can speak Spanish. Luis is from El Salvador and he speaks Spanish and struggles to read and write in English. Mariana is of Mexican descent, was born in the United States and she struggles with literacy in English and Spanish. Noemí is from Ecuador and moved to the United States in the 8th grade and is expanding her oracy in English and struggles with English literacy. Teresita moved to the United States from Guatemala when she was young and her oracy and literacy performances in English and Spanish are commanding" (GARCÍA; JOHNSON; SELTZER, 2017, p. 130). 
awareness (for example, the ability to perceive similarities in syntax, vocabulary etc. in both languages). Students choose to read it in one language or another, or both. This is already a democratic exposure and stance on the part of the teacher, as claimed by García, Johnson, Seltzer (2017). Through the directions in the handout, students are instructed to read this biography and annotate in English, Spanish, or both: a) unknown vocabulary words, b) cognates, c) meanings, d) main ideas, e) stars next to important aspects, f) a question mark for confusing parts. They are also supposed to take notes on: a) ideas they agree or disagree with, b) interrogations they might have, c) connections, d) predictions, and e) summaries. This is a strategy for the students to dialogue with the text while developing their "intrapersonal translanguaging by reading it independently" (GARCÍA; JOHNSON; SELTZER, 2017, p. 134).

The authors explain that Stephanie selected César Chávez' biography to highlight the Latino historical figure and reconnect it to the lives of her students. Stephany's stance expanded the curriculum through exploring localized teaching while making space for her students to have a sense of social justice. Social justice, in this case, pushed students to access other voices and stories that were historically unrepresented. She understood the classroom as a space for the development of bilingual and non-bilingual students' awareness of social inequities. Also by doing some research to select texts, from diverse websites, with different views on Chávez' legacy, in different languages, she sees heterogeneity as a richer aspect instead of a deficit. In this way, "she scaffolds her instruction to support students' learning [...] and translanguaging helps students understand texts in deeper ways than they would if they were speakers of only one single language.” (GARCÍA; JOHNSON; SELTZER, 2017, p. 131-132).

These authors report that Stephanie prepared a jigsaw reading organizing her students in more or less homogeneous groups in terms of English previous experience. By using their annotations and notes, students were to discuss them in groups and answer three questions in a handout. The instructions included (GARCÍA; JOHNSON; SELTZER, 2017, p. 135):

Share your thoughts and questions with your group. In your group answer the following questions about our assigned text (write in English, Spanish, or both):

${ }^{11}$ A Mexican American activist and union leader in defense of rural workers in the USA. 
1. What do you think is the most important idea from this reading?

2. What is the message about Cesar Chávez given by the author?

3. Do you agree or disagree with this message? Why?

A reminder was placed at the bottom of the handout, which reads: "Remember: Once you join your new groups, you will be the only expert on your reading, so make sure you know what you're talking about!” (GARCÍA; JOHNSON; SELTZER, 2017, p. 135).

\section{EXERCISING CREATIVITY AND (SELF)CRITIQUING, DOING AND COLIVING OTHERWISE WITH STEPHANIE AND EDUCATORS JUNTOS: TOWARDS AN EXPANSION OF STEPHANIE'S LESSON}

One of the interesting aspects in Stephanie's class starts by her foregrounding the inclusion of a theme from the students' hometowns or countries of origin. They have a sense of belonging, willingness to share their cultural richness and learn from the others, a key initiative to amplify the ethical dimensions of meaning making.

I understand that our choices have historical and pedagogical implications and more than pursuing a desire for completeness, creating a safe environment for the students to feel comfortable, as Stephanie did, is fundamental. To exercise their potential for (self)critique presupposes an ongoing process of experimenting with complex dialogues with ideas other than those safeguarded by common sense. Furthermore, navigating within ambiguities and uncertainties juntos with the radical other (for instance, the global North) might be helpful in the reinvention of the translingual space around us-them.

The outlined context of teaching here leads me to put myself in Stephanie's shoes and support my own (self)critique to reflect together with her, or put better, to reflect juntos. At this stage, some more questions arise on my mind and, who knows, they somehow could be Stephanie's or another teacher's interrogations in retrospect: How is academic rhetoric of ethics interweaved with the actual practices in this classroom and with a broader political concern? How can we seek to work with students in ways that they develop a wider understanding of the context in which they are practicing translanguaging and learning English(es)? What if we had transposed (self)critically the multiliteracies theoretical approach (THE NEW LONDON GROUP, 1996) transforming graphocentric routines to be more compatible with her students' lives, in the curriculum?

Enhancing opportunities for the socialization of meaning making on collaborative 
mode might transcend linearity. Synesthesia also responds to the blurring of languages and reappropriations on the part of the students' creativity, that is, "following or floating norms of language use" (GARCÍA; WEI, 2014, p. 24). Additionally, as the world seems to be increasingly shaped by multi-modes of communication (the profusion of semiotic resources such as images, gestures, gaze, signs and sounds in hypermedia), what to do with Chávez image in the handout? How would it be interpreted thinking of visual and spatial literacies and also confronting it to other Chávez' portraits and images from the materials found on the Internet?

In this vein, I would add further questions for us to create and (self)critique otherwise juntos: How can we reflect upon our (self)critical stance when we pin point a celebrity, as in the case of Chavéz? Would it, inadvertently, lead students to think of a role model to be pursued as if it were the only possibility in life? How can we work on texts about famous/notorious people moving away from the reinforcement of a homogeneous sense of success/failure in life, which resembles westernized worldview and mainstream literacy? What is patently visible in the Chavéz' biography and what is 'not there' (unexamined subtexts to our own self(critique) but performatively possible to be brought into being?

How can these interrogations establish more dialogues with the following evaluation: "Stephanie's view of bilingualism as a resource for creativity and criticality shines through all aspects of her thinking about content and literacy instruction" (GARCÍA; JOHNSON; SELTZER; 2017, p. 131)? Are biographies dealt with in this way exempt from the incorporation of political issues at this stage of the lesson, of students' body expressions, in light of the theoretical framework of translanguaging/translingual practices (even bearing in mind Stephanie developed subsequent additional activities in which the students had to play different roles with more diversified semiotic resources within asymmetrical relationships with/of Chávez)? How can we move from an instrumentalist perspective of reading (as the activity in the handout shows) to agentive critical literacy (LUKE, 2012) for which "power is always contingent" (LUKE, 2019, p. 206)?

I miss questions like these ones in Stephanie's work with Chávez' biography with her students. Also, the nature of such questions reinforce García and Wei's (2014) characterizations of translanguaging based on creativity and criticality as previously 
mentioned. Creative and critical in the sense of disrupting common sense and, therefore, enhancing meaningful knowledge construction out of the students' personal engagement with different life stories, in broader political problematizations of the subject matter.

It might be pertinent to ask how the questions (1-3) in the handout promote bias and/or monopolize interpretations, if any, or 'let pass' essentialist discourses related to Chávez unnoticed by teacher and students. Another key point is to interrogate what would be possible to change in such questions for the students to undermine and subvert mainstream ontology-epistemology-methodology (TAKAKI, 2016, 2019a, 2020), reconstruct meanings, further social actions to renegotiate their social relations with one another, think of their implicature, also as a contingent social practice in the exercise of power? Is the choice of material per se responsible for change (e.g.: in reflections, futural imaginings, beliefs, ethical attitude, positionings, strategies, dialogical renegotiations of meanings), or is it the way to approach it that counts?

In principle, any kind of supplementary material can provide opportunities for the teacher to enable students to interact with the author and make visible power relations in society. In the case of the biography, it appears to be a mere vehicle through which Chávez' life was described. So, thinking with Stephanie, how could we empower the students to constantly build on previous and future encounters in their unique search for understanding of who they are as social agents capable of reconstructing their identities and envisaging collective literacies outside mainstream ideals? Why and how certain discourses, texts, practices, micro-relations, semiotic resources count (as in the case of Chávez) more than others might also engage students with more curricular 'control', with difference "not merely in terms of inclusiveness and issues but also at the level of desire" (PENNYCOOK, 1999, p. 341). Issues related to violence, as the cited author states.

Transgressing norms and expectations can be a risky business for a teacher to renegotiate otherness in similar and in dissimilar contexts, and for students who are classified as minoritized, immigrant pupils/learners. We all know schools are not an easy environment. This is a point (self)critique recognizes and for which there are no finished and fixed answers but rather it seeks to pursue a shared common agenda in terms of interculturality (WALSH, 2007). It means a "permanent and active process of negotiation and interrelation in which difference does not disappear" (WALSH, 2018, p. 59), which reflects the constant problematizations of our own expansion of possibilities. 
A useful reminder reflects the concepts of language and knowledge and (self)critique with which we incorporate the students in our daily praxis and approach to allow them to be the teachers they want to/can be without suppressing part of their entire language repertoire, as Canagarajah (2017) argues. To increase students' life chances, it seems vital to revise how the such concepts inflected by other axes of socially salient differences (for instance those of race, ethnicity, generation, class, culture) interfere in our devising of lesson plans, projects and research. Also, it is crucial to rethink how they might hinder learning opportunities, if we find (self)critique somehow useful for translanguaging/translingual practices.

Approaching criticality (GARCÍA; WEI, 2014) juntos through the previous questions is not in vain, for educators are normally interested in understanding how complexity has been shaping and transforming (more or less, or not) content-based area and bilingual/multilingual contexts. How to make students from transnational migration contexts engage in class to perceive how positions of power, authority in certain semiotic resources and solidarity are enacted and/or contested would also require insights from research ethnography (HELLER; PIETIKÄINEN; PUJOLAR, 2018) and reflexive ethnography (MARTIN-JONES; ANDREWS; MARTIN, 2017) in the translanguaging classroom. As Canagarajah (2017, p. 631) puts: "features of the body (such as gaze, gesture, posture, proximity, and positioning) have also not been giving adequate significance in multilingual interactions." These are features of "the spatial orientation" that "expands multimodal analysis", this theorist argues (2017, p. 640). In addition, the question of students' silence deserves further attention.

A respectful and culturally sensitive approach to understand what goes on and what matters, how meaning evolves from in particular research contexts, from the researcher and from the participants' world views is more congruent with ethnographic insights. It comprises participant observation of individuals and groups of individuals, interviews, documentary analysis, the researchers' field notes and his/her self(critical)/ reflexive meaning making associated with the research process and results. Research ethnography addresses ethical questions in in-depth contextualized explorations of specific social, cultural, political and economic conditions in which the processes unfold (HELLER; PIETIKÄINEN; PUJOLAR, 2018).

Hard times require tough questions and this is inherent to the process of practicing 
(self)critique by posing new issues. Nonetheless, a kind of ongoing autoethnography (TAKAKI, 2020) might be desirable in the search for a broader understanding of what is going on inside or outside the translanguaging classroom, in life. Seeing in this way, one would ask Foucault, Derrida, Bakhtin, Deleuze, to name a few, how they would go about revisiting their theories in contemporary complexity in the light of decolonial perspectives (MIGNOLO, 2018, DUSSEL, 2007, QUIJANO, 2018) and southern views (SOUSA SANTOS; MENDES, 2018, SOUSA SANTOS, 2009, MENEZES DE SOUZA, 2019). Moreover, it would be relevant to ask them how to understand theory-practice in ways to distance ourselves-themselves from colonizing systems considering locality (APPADURAI, 1996), that is, global-local spaces that feed each other incessantly.

More than mere sets of questions, (self)critique processes are like waves that come and go problematizing what the neoliberal ocean does with us-them and how we-they construct vitality for all after being in contact with its elements. Neither its elements, nor we-they are the same after crisscrossing an embodied experience such as this. A defining feature arises: submerging and emerging norms and assumptions for us-them to reconstruct our-their stories are crucial to translanguaging/translingual practices from (self)critical dialogues. Such dialogues are usually unresolved and subject to resignifications.

By (self)critical southern and decolonial perspective, I mean a form of translingual education (formal, informal instructions) with special attention to public education that goes beyond the mere resistance. Juntos with the radical colonizers, adversaries instead of enemies (MOUFFE, 2013), towards the elaboration of intersubjectivities otherwise. Intersubjectivities otherwise include the world visions of minoritized people and of the nonhumans (BRAIDOTTI, 2018, PENNYCOOK, 2018), with which we-they are in debt.

\section{CONSIDERATIONS: INTERSECTING AND BECOMING JUNTOS}

The intersection between translanguaging/translingual practices, creativity and (self)critique can be explored through interrogating taken-for-granted norms and assumptions including my own and those that have historically separated transnational theory from practice. It recognizes social and community inequities and also the students' agency for empowerment and action. It amplifies (or not) the students, teachers, 
authorities' horizons to make informed choices, advocating for transformative agency. While dealing with texts in classroom, students can be encouraged to understand and reinterpret the ideologies of resources and repertoires within which discourses are constructed. In other words, going beyond the recognition of differences and rethinking about their implications for diverse students' contexts. Luke (2012, p. 2) clarifies the aim of critical literacy, which is pertinent to self(critique) in the following citation:

Critical literacy has an explicit aim of the critique and transformation of dominant ideologies, cultures and economies, and institutions and political systems. As a practical approach to curriculum, it melds social, political, and cultural debate and discussion with the analysis of how texts and discourses work, where, with what consequences, and in whose interests.

Thus, interrogating the ideological system with which biographies/discourses are constructed and reconstructed means thinking of the consequences of such positionings transiting within other sociopolitical students' identities, issues and cultures at the same time. However, Luke (2019, p. 177) reminds us that "the power of literacy, in all its variable forms, is contingent." In the same line of thought, reading with and against texts for literacy is embedded in power relations is desirable (JANKS, 2010). Both Janks (2010) and Luke (2012) draw on Freire's educational project (2005), for which (self)critique purports to ask questions juntos to ourselves-themselves (to authors of texts) while redesigning local-global meanings and agency.

Going further, as a tentative to answer my own questions, I would reiterate the inherent interconnection existing in ontologies-epistemologies-methodologies (TAKAKI, 2016, 2019a, 2020). It would mobilize forces to enable understanding the fact that renegotiations among participants in the classroom and in research are shaped by the institutional dimension in which we-they are blended. In this way, self(critique) juntos is more likely to reverberate bilingual/multilingual students' active engagement and their associations and avoid reproducing an essentialist view of the minoritized nation culture and language.

It is worth reminding that in order to ground (self)critical literacies, translanguaging/translingual practices can/should be understood as a political resource that is mutable and that calls for the readers' ability to ressignify meanings and move away 
from colonial modes and practices. In this regard, Janks (2010, p. 176) claims that:

Critical language awareness emphasizes the fact that texts are constructed. Anything that has been constructed can be de-constructed. This unmaking or unpacking of the text increases our awareness of the choices that the writer or speaker has made. Every choice foregrounds what was selected and hides, silences or backgrounds what was not selected.

Hence, (self)critical awareness can draw on the ideas in the above citation and go beyond them through the deployment of ideas, values, domestic language, cultural homeland experience, embodied discursive practice, narratives about race, class, gender etc. Attracting the dominant social groups, who are also being weakened by the power of nature ('natural' disasters, ironically caused by their corporations) or by our-their causes (corona viruses, for example) may be a choice in search of a world reconstruction.

Creative and (self)critical lens count on the previous characteristics in sociocultural spaces with different dimensions of personal narratives, experiences, environment, contingent on local attitude, in fluid overlapping rather than stable and universal definitions. (Self)critique brings back these very features to ourselvesthemselves. It is a way of coliving, self(critique) is a decolonial option (MIGNOLO, 2018) instead of an imposition. It is worth embarking on a different project with a view to expand on the teachers and students' interpretations, but not with the intention to provide a recipe for what, how, why, with whom, as one-size does not fit all. The set of questions displayed here does not refer to mere procedures: there are other ways to promote (self)critical, ethical and creative translanguaging/translingual practices under constant repositioning.

Possible (self)critique can be delineated with some bases as listed below, if there is a willingness to work juntos:

a) Awareness that theories of (self)critique may/should be more profoundly explored in translingual decolonial and Southern perspectives juntos is desirable;

b) Not missing opportunities to entice students to develop their creativity and critique (GARCÍA; WEI, 2014), (self)critique, here, in reading texts/events/ universe might be a good start considering the socio-cultural, historical and political differences inside the same classroom; 
c) Listening, unlearning and reconstructing meanings resorting to available and emerging repertoires presupposes "reading the word and the world" (FREIRE; MACEDO, 1987) and also recognizing the validity of (un)easy dialogues;

d) Reconnecting ontology-epistemology-methodology in ecological and dynamic fashion means re-conquering the adversaries (MOUFFE, 2013) too;

e) Transforming official national exams and assessments in decolonial ways to favor bilinguals/multilinguals;

f) Co-agency and coliving otherwise might imply inviting immigrants to be codesigners of programs and co-policy makers.

It is in the hope that such principles might contribute to the educational and intellectual growth of the students, teachers, researches and authorities inside and outside this field that I have sought to reflect (self)critically juntos here.

\section{REFERENCES}

APPADURAI. A. Modernity at large: cultural dimensions of globalization. Minnesota: University of Minnesota Press, 1996.

BRAIDOTTI, R. The posthuman. Cambridge: Polity Press, 2018.

CANAGARAJAH, S. Introduction. The nexus of migration and language. The emergence of a disciplinary space. In: CANAGARAJAH, S. (Ed.) The Routledge handbook of migration and language. London, New York, p. 290-1102, 2017.

CANAGARAJAH, S. Translingual practice: global Englishes and cosmopolitan relations. London: Routledge, 2013a.

CANAGARAJAH, S. (Ed.) Introduction. In: CANAGARAJAH, S. (Ed.) Literacy as translingual practice. Between communities and classrooms. New York, London, Routledge, p. 1-10, 2013 b.

CANAGARAJAH, S. Translanguaging in the classroom: emerging issues for research and pedagogy, 2011. Available at: <https://www.researchgate.net/ publication/279558643_Translanguaging_in_the_Classroom_Emerging_Issues_for_Resea rch_and_Pedagogy>. Access on: 12 oct. 2019.

CREESE, A.; BLACKLEDGE, A. Translanguaging in the bilingual classroom: a pedagogy for learning and teaching? The Modern Language Journal, v. 94, n. 1, p. 103$115,2010$. 
DELEUZE, G. Conversações. Tradução de Peter Pál Pelbart. São Paulo: Editora 34, 2003.

DELEUZE, G.; GUATTARI, F. A thousand plateaus: capitalism and schizophrenia. Translation and foreword by Brian Massumi. Minneapolis: Published by the University of Minnesota Press, 2005.

DERRIDA, J. Of Grammatology. Baltimore: The Johns Hopkins University Press, 1997.

DUSSEL, E. Transmodernity and Interculturality: An Interpretation from the Perspective of Philosophy of Liberation, 2012.

FREIRE, P. Pedagogia da tolerância. São Paulo: Editora da UNESP, 2005.

FREIRE, P.; MACEDO, D. Alfabetização: leitura do mundo leitura da palavra. Rio de Janeiro: Paz e Terra, 1987.

GARCÍA, O.; LIN, A. M. Y. 2016. Translanguaging in bilingual education. Available at: $<$ https://ofeliagarciadotorg.files.wordpress.com/2011/02/translanguaging-in-bilingualeducation.pdf $>$ Access on: 08 jun. 2019.

GARCÍA, O.; WEI, L. Translanguaging. Language, bilingualism and education. New York: Palgrave, MacMillan, 2014.

GARCÍA, O.; KLYEN, T. Translanguaging with multilingual students. Learning from classroom moments. New York, London, Routledge, 2016.

GARCÍA, O; JOHNSON, S. I.; SELTZER, K. The translanguaging classroom: leveraging student bilingualism for learning. Philadelphia, PA: Caslon, 2017.

KRESS, G. Multimodality. A social semiotic approach to contemporary communication. London: Routledge, 2010.

HELLER, M.; PIETIKÄINEN, S.; PUJOLAR, J. Critical sociolinguistics research methods. Studying Language Issues that Matter. New York, London: Routledge, 2018.

JANKS, H. Literacy and power. London, New York: Routledge, 2010.

KUMARAVADIVELU, B. The decolonial option in English teaching: Can the subaltern act? TESOL Quarterly, v. 50, n. 1, p. 66-81, 2016.

LU, M-Z.; HORNER, B. Translingual literacy and matters of agency. In: CANAGARAJAH, S. (Ed.) Literacy as translingual practice. Between communities and classrooms. New York, London, Routledge, p. 26-38, 2013.

LUKE, A. Educational policy, narrative and discourse. New York, London: Routledge, 2019. 
LUKE, A. Critical literacy: Foundational notes. Theory into practice, v. 51, n. 1, p. 4-11, 2012.

MARTIN-JONES, M.; MARTIN, D. Reflexive autoethnographic research practice in multilingual context. In: MARTIN-JONES, M.; ANDREWS, J. MARTIN, D. (Eds.) Researching multilingualism. Critical ethnographic perspectives, p. 189-202, 2017.

MENEZES DE SOUZA, L. T. Introduction. Theorizing the South(s). In: FINARDI, K. R. (Org.) English in the South. Londrina: EDUEL, 2019.

MIGNOLO W. Delinking. The rhetoric of modernity, the logic of coloniality and the grammar of de-coloniality. 2007.2 Available at: $<$ https://www.tandfonline.com/doi/full/10.1080/09502380601162647>. Access on: 10 set. 2019 .

MIGNOLO, W. D. The decolonial option. In: MIGNOLO, W. D.; WALSH, C. On decoloniality. Concepts. Analytics. Praxis. Durham, London: Duke University Press, p. 105-259, 2018.

MOUFFE, C. Agonistics. Thinking the world politically. London, New York: Verso, 2013.

OTHEGUY, R.; GARCÍA, O; REID, W. Clarifying translanguaging and deconstructing named languages: A perspective from linguistics. Applied Linguistics Review, v. 6, n. 3, p. 281-307, 2015.

PRATT, M. L. Arts of the Contact Zone. Profession, New York: MLA, v. 91, p. 33-40, 1991.

PENNYCOOK, A.; MAKONI, S. Innovations and challenges in Applied linguistics from the global South. London, New York: Routledge, 2020.

PENNYCOOK, A. Posthumanist applied linguistics. New York: Routledge, 2018.

PENNYCOOK, A. Global Englishes and transcultural flows. New York, London: Routledge, 2006.

PENNYCOOK, A. Introduction. Critical approaches to TESOL. TESOL Quarterly, v.33, n.3, 1999.

QUIJANO, A. Coloniality and modernity/rationality. In: MIGNOLO, W. ESCOBAR, A. (Eds.) Globalization and the decolonial option. London, New York: Routledge, p. 22-32, 2013.

RANCIÉRE, J. Dissensus: On Politics and Aesthetics. New York: Continuum International Publishing Group, 2010. 
RICOEUR, P. O conflito das interpretações: ensaios de hermenêutica. Rio de Janeiro: Imago, 1978.

SOUSA SANTOS, B. Para uma nova visão da Europa: aprender com o Sul. In: SOUSA SANTOS, B.; MENDES, J. M. (Orgs.) Demodiversidade. Imaginar novas possibilidades democráticas. Belo Horizonte: Autêntica, p. 51-72, 2018.

SOUSA SANTOS, B. Para além do pensamento abissal: das linhas globais a uma ecologia dos saberes. In: SOUSA SANTOS, B.; MENESES, M. P. (Orgs.). Epistemologias do Sul. Coimbra: Livraria Almedina, p. 30-65, 2009.

TAKAKI, N. H. Epistemologia-ontologia-metodologia pela diferença: lócus transfronteira em ironia multimodal. Trabalhos em Linguística Aplicada, v. 55, n. 2, p. 431-456, 2016.

TAKAKI, N. H. É o que somos, sendo: o papel da (auto)crítica nos letramentos. IN: FERRAZ. D. M.; KAWASHI-FURLAN, C. J. (Eds.) Bate-papo com educadores linguísticos: letramentos, formação docente e criticidade. São Paulo: SP, PimentaCultural, p. 197-216, 2019a.

TAKAKI, N. H. Thought-provoking 'contamination': Applied Linguistics, Literacies and Posthumanism. Trabalhos em Linguística Aplicada, v. 58, n. 2, p. 579-611, 2019 b.

TAKAKI, N. H. Por uma autoetnografia/autocrítica reflexiva. Inter Letras, v. 8, edição 31, p. 01-19, 2020.

THE NEW LONDON GROUP. A pedagogy of multiliteracies: designing social futures. 1996. Available at:

$<$ http://newarcproject.pbworks.com/f/Pedagogy+of+Multiliteracies_New+London+Group. pdf> Access on: 15 jul. 2019.

WALSH, C. Interculturalidad y colonialidad del poder. Un pensamiento y posicionamiento "otro" desde la diferencia colonial. In: CASTRO-GOMES, S.; GROSFOGUEL, R. l giro decolonial: reflexiones para una diversidad epistémica más allá del capitalismo global/compiladores. Bogotá: Siglo del Hombre Editores; Universidad Central, Instituto de Estudios Sociales Contemporáneos y Pontifi cia Universidad Javeriana, Instituto Pensar, p. 47-62, 2007.

WALSH, C. Interculturality and decolonilaity. In: MIGNOLO, W.; WALSH, C. On decoloniality. Concepts. Analytics. Práxis. Durham, London: Duke University Press, p. 57-80, 2018.

ZEICHNER, K. Teacher education for social justice. In: HAWKINS, M. R. (Ed.). Social justice language teacher education. Bristol, UK: Multilingual Matters, p. 7-22, 2011.

Recebido em: 13 dez. 2019.

Aceito em: 10 abr. 2020. 